\title{
Effect of 'Candidatus Liberibacter solanacearum' on Fitness of Its Insect Vector, Bactericera cockerelli (Hemiptera: Triozidae), on Tomato
}

\author{
Punya Nachappa, Ana Austin Shapiro, and Cecilia Tamborindeguy
}

Department of Entomology, Texas A\&M University, College Station 77843.

Current address of A. A. Shapiro: Colby College, 4000 Mayflower Hill, Waterville, ME 04901.

Accepted for publication 16 August 2011.

\section{ABSTRACT}

Nachappa, P., Shapiro, A. A., and Tamborindeguy, C. 2012. Effect of 'Candidatus Liberibacter solanacearum' on fitness of its insect vector, Bactericera cockerelli (Hemiptera: Triozidae), on tomato. Phytopathology 102:41-46.

The potato/tomato psyllid, Bactericera cockerelli transmits the bacterium 'Candidatus Liberibacter solanacearum', also known as ' $\mathrm{Ca}$. L. psyllaurous', which causes zebra chip disease in solanaceous crops. There have been no studies addressing the effect of the bacterial plant pathogen on the biology of its insect vector. We examined several life-history traits, including 7-day fecundity, hatching percentage, incubation time, nymphal survival percentage, nymphal development time, total development time, and sex-ratio of ' $\mathrm{Ca}$. L. solanacearum'-positive and -negative psyllid isofemale lines on tomato, as well as adult mortality index of ' $\mathrm{Ca}$. $\mathrm{L}$. solanacearum'-positive and -negative insects. The only two life-history traits that differed between the ' $\mathrm{Ca}$. L. solanacearum'-positive and -negative psyllid isofemale lines were 7-day fecundity and nymphal survival percentage, which were significantly lower in ' $\mathrm{Ca}$. L. solanacearum'positive lines. The symbiotic bacteria associated with both psyllid isofemale lines were similar, with the exception of ' $\mathrm{Ca}$. L. solanacearum', which showed $100 \%$ infection in the ' $\mathrm{Ca}$. L. solanacearum'-positive lines and was not detected in the negative psyllid lines. These results suggest that ' $\mathrm{Ca}$. L. solanacearum' has a negative effect on population growth rate of its insect vector on tomato.
The potato/tomato psyllid Bactericera cockerelli (Šulc) (Hemiptera: Triozidae) is a phloem-feeding insect and has an extensive host range which includes plant species in 20 families, with a strong preference for solanaceous species (29). The potato psyllid is commonly found in western Texas, Oklahoma, Kansas, Nebraska, South Dakota, North Dakota, Minnesota, California, and the Pacific Northwest (including Washington and Oregon) as well as in Mexico and some countries in Central America (5). Previous reports suggest that the insect appears to migrate annually with wind and high temperatures in late spring to northern states from its overwintering and breeding areas in western Texas, southern New Mexico, Arizona, California, and northern Mexico $(23,29)$. The potato psyllid is associated with two types of plant disorders: (i) psyllid yellows and (ii) zebra chip (ZC) disease. ZC disease was first reported in Mexico in the 1990s and, by 2004-05, the disease had spread to parts of Texas. Currently, ZC has been detected in the southwestern and central United States, Mexico, and Central America (5), and was also reported in New Zealand (11). Recent studies identified a new bacterium species, 'Candidatus Liberibacter solanacearum', also known as ' $C a$. L. psyllaurous', as the causal agent of ZC disease $(1,4,7,11,12)$. The bacterium is a member of the class Alphaproteobacteria, and is closely related to ' $\mathrm{Ca}$. L. asiaticus', ' $\mathrm{Ca}$. L. africanus', and ' $\mathrm{Ca}$. L. americanus', bacteria that are associated with Huanglongbing (citrus greening) disease in Asia, Africa, and the Americas $(7,12,13)$. On potato, psyllid yellows and ZC disease are characterized by yellowing of leaves, aerial tubers, shortened thickened internodes, stunted plant growth, and reduced fruit and tuber size

Corresponding author: $\mathrm{C}$. Tamborindeguy

E-mail address: ctamborindeguy@ag.tamu.edu

http://dx.doi.org/10.1094/PHYTO-03-11-0084

(c) 2012 The American Phytopathological Society
$(18,19,24,25)$. ZC disease also affects the tubers, causing internal browning of raw tubers and very dark chip color when the tubers are fried $(18,19)$. The coloration of the fried tubers often shows as rays or stripes; hence, the common name "zebra chip". In tomato, the pathogen causes chlorosis, stunting and reduces yields (http://cisr.ucr.edu/potato_psyllid.html). Plants are known to recover from psyllid yellows when psyllids are removed, but not from ZC (25). Hence, $B$. cockerelli is not only a pest of solanaceous crops but also transmits the bacterium that causes $\mathrm{ZC}$.

The biology and life history of $B$. cockerelli has been documented since the early 1930 s under varying laboratory conditions. However, there is considerable variation in potato psyllid biology reported in the literature. For example, Wallis (29) reported that the fecundity of a single female was 500 eggs whereas Abdullah (2) showed that female potato psyllids can deposit an average of 231.8 eggs on tomato. Nymphal development time has been reported to occur over a range of 12 to 21 days $(9,22)$, depending on temperature. In the last 5 to 6 years, there have been several indepth studies on the biology and life history of the potato psyllid on several host plants including potato (32), eggplant and pepper (31), and tomato $(2,14,15)$. These studies have contributed to the understanding of the biology and population dynamics of this important insect pest and vector. However, to our knowledge, there have been no studies addressing the effect of the bacterial plant pathogen ' $\mathrm{Ca}$. L. solanacearum' on life-history traits of the potato psyllid.

In addition to ' $\mathrm{Ca}$. L. solanacearum', three other prokaryotic intracellular bacteria (symbionts) are associated with the potato psyllid: the primary $(\mathrm{P})$ or obligate symbiont (Carsonella ruddii) $(20,28)$ and two facultative symbionts, a secondary (S) symbiont $(6,27)$ and two different Wolbachia strains $(16,20)$. These symbionts are heritable and transmitted from mother to offspring (3). The $\mathrm{P}$ symbiont influences fundamental biological processes in their insect host and is required for survival and development of 
the psyllid (3), whereas the facultative symbionts can influence ecologically relevant fitness traits of their hosts $(6,21)$. For example, Wolbachia spp. can manipulate host reproduction in that they provide infected female hosts with a reproductive advantage relative to uninfected females, ultimately resulting in spread of Wolbachia spp. through populations (30). Furthermore, Wolbachia spp. were shown to directly inhibit the ability of two distantly related arboviruses and the malaria parasite, a Plasmodium sp., from establishing productive infections in the mosquito host (17). Knowledge of the symbiotic bacteria in insect vectors can provide information about disease epidemiology because they may influence fecundity or survival of the insect, resulting in increased frequency of vectors or pathogen transmission. The goal of the current study was to determine the effects of the plant pathogen 'Ca. L. solanacearum' on its insect vector, B. cockerelli. Specifically, we examined several life-history traits of ' $\mathrm{Ca}$. L. solanacearum'-positive and -negative potato psyllids on tomato plants using an isofemale line approach. Further, we determined the symbiotic microbiota associated with ' $\mathrm{Ca}$. L. solanacearum'-positive and -negative isofemale lines to rule out the possibility that symbiotic bacteria other than ' $C a$. L. solanacearum' may be responsible for differences in psyllid fitness.

\section{MATERIALS AND METHODS}

Insect source. The ' $C a$. L. solanacearum'-positive and -negative source colonies of $B$. cockerelli were field collected from Weslaco, TX in 2008 and shipped to our laboratory at Texas A\&M University, College Station. The 'Ca. L. solanacearum'-positive and -negative colonies were maintained in separate 14-by-14-by24-in. insect cages (BioQuip, Rancho Dominguez, CA). The colonies were maintained on ' $C a$. L. solanacearum'-negative tomato plants under laboratory conditions with temperature of $24 \pm 1{ }^{\circ} \mathrm{C}$ and a photoperiod of 12 and $12 \mathrm{~h}$ (light and darkness). These colonies have been maintained in our laboratory for $>2$ years ( $\approx 24$ generations). Diagnostic polymerase chain reaction (PCR) analyses are performed routinely to confirm presence or absence of ' $\mathrm{Ca}$. L. solanacearum' in both psyllid colonies, as described by Nachappa et al. (20).

Host plants. Tomato plants (Solanum lycopersicum L. 'Moneymaker') (Victory Seeds, Molalla, OR) were used for all experiments. Plants were grown in 4-in. pots with Sun-Gro Sunshine LP5 mix (Bellevue, WA) and fertilized twice a week with the label rate of Miracle-Gro Water-Soluble Tomato Plant Food (18-18-21, NPK) (Scotts Company, OH). Plants used for experiments were 4 to 5 weeks of age.

Isofemale lines. ' $C a$. L. solanacearum'-positive and -negative psyllids were used to initiate isofemale lines. Prior to starting isofemale lines, 20 to 30 newly emerged adults (1 to 2 days old) of both sexes were collected from ' $\mathrm{Ca}$. L. solanacearum'-positive and -negative source colonies and transferred to a ' $\mathrm{Ca}$. L. solanacearum'-negative tomato plant in separate 14-by-14-by-14-in. insect cages and allowed a 7-day mating period. After the 7-day mating period, single mated females from ' $\mathrm{Ca}$. L. solanacearum'-positive and -negative colonies were transferred to ' $\mathrm{Ca}$. L. solanacearum'-negative tomato plants in individual cages of the same dimensions mentioned above. All insect cages were arranged on shelves in the laboratory. Females were allowed a 7 -day oviposition period. The adult female psyllids were removed after the 7-day oviposition period and placed in a $-20^{\circ} \mathrm{C}$ freezer for DNA extraction and PCR analysis. If an adult female psyllid could not be retrieved or was found dead before the 7-day oviposition period, a new isofemale line was initiated. The number of offspring including eggs, all five nymphal instars, incubation time of eggs, nymph development, and total development time were recorded daily in each isofemale line. Nymphal instar determination was made based on size of the nymphal instar and the development of wing pads. The adults emerging from the last nymphal stage were collected and sexed for recording the sex ratio. An isofemale line was terminated when the last nymphal instar completed development to the adult stage. Three biological replicates were conducted during July and August 2010 (experiment 1), November and December 2010 (experiment 2), and January and February 2011 (experiment 3). In each biological replicate or experiment, 4 to 10 isofemale lines were initiated. There were 17 isofemale lines for ' $C a$. L. solanacearum'-positive psyllids and 18 isofemale lines for ' $\mathrm{Ca}$. L. solanacearum'-negative psyllids. All experiments were conducted under the laboratory conditions mentioned previously.

Adult longevity and survival assay. In separate experiments, we evaluated longevity and survival of ' $\mathrm{Ca}$. L. solanacearum'positive and -negative psyllids under similar laboratory conditions on tomato plants. Newly emerged individuals of both sexes from the ' $\mathrm{Ca}$. L. solanacearum'-positive and -negative colonies were placed on ' $\mathrm{Ca}$. L. solanacearum'-negative tomato plant in separate insect cages (of the same dimensions mentioned previously). Adult mortality in each cage was recorded daily until all adults were dead. Adult mortality and longevity was determined as a function of a mortality index. The mortality index was calculated using the following formula: $M i=n D \times L s$, where $M i$ is mortality index on day $i, n D$ is number of dead individuals per day, and $L s$ is the duration of the life span of those insects (days). The greater the mortality index, the longer it took for adults to perish. Two biological replicates were conducted during December 2010 and January 2011. There were 45 replicates (individuals) for the ' $\mathrm{Ca}$. L. solanacearum'-positive and -negative psyllid colonies.

DNA extraction and PCR analyses. DNA extraction was performed on individual adult psyllids as described by Nachappa et al. (20). Adult females that were used to initiate the ' $C a$. L. solanacearum'-positive and negative isofemale lines were retrieved after the 7-day oviposition period and used for molecular analyses. Individual psyllid DNA extractions were used in multiplex PCR amplification assays to detect symbiotic bacteria, including the $\mathrm{P}$ and $\mathrm{S}$ symbiont and ' $\mathrm{Ca}$. L. solanacearum' along with $28 \mathrm{~S}$ rDNA (internal control), respectively, according to Nachappa et al. (20). To test the presence of Wolbachia spp., primers that amplified the Wolbachia surface protein ( $w s p$ ) gene (wsp-81F and wsp-691R) were used as per Liu et al. (16). Wolbachia strain wBacl was amplified using 5'-AAAAGCAT CTTTTCTCGCTGGA-3' and 5'-TTTTTATCACCAGTAACCT CTGTT-3' forward and reverse primers, respectively. Wolbachia strain $w B a c 2$ was amplified using 5'-TATAGCTGCTGGTGG TGCAT-3' and 5'-AACTGTATCAGCTTTTGAAGGATTG-3' forward and reverse primers, respectively.

The wsp PCR assay was performed using the following conditions: $94^{\circ} \mathrm{C}$ for $2 \mathrm{~min}$; followed by 35 cycles of $94^{\circ} \mathrm{C}$ for $30 \mathrm{~s}$, $55^{\circ} \mathrm{C}$ for $1 \mathrm{~min}$, and $72^{\circ} \mathrm{C}$ for $1 \mathrm{~min}$; and a final extension at $72^{\circ} \mathrm{C}$ for $5 \mathrm{~min}$. The PCR products were resolved on $1 \%$ agarose gel, stained with ethidium bromide, and visualized with a digitally documented using the Foto/Analyst Investigator photographic system with Image J 1.34s software (Fotodyne, Hartland, WI).

Sequencing of amplicons to verify specificity. For all symbiotic bacteria, with the exception of Wolbachia spp., simplex PCR reactions were performed using the conditions as described by Nachappa et al. (20). PCR products were purified with the Purelink PCR Purification Kit (Invitrogen, Carlsbad, CA) following manufacturer's protocol and the products sequenced at the DNA Technologies Core Laboratory at Texas A\&M University. Wolbachia wsp PCR amplicons from pooled DNA extracts of 10 ' $C a$. L. solanacearum'-positive and 10 'Ca. L. solanacearum'-negative psyllids were cloned into pCR4-TOPO vector (TOPO TA cloning kit; Invitrogen) in Escherichia coli cells following the manufacturer's protocol. Colonies containing a plasmid with an insert of the correct size were checked by PCR. The PCR conditions were the same as those mentioned previously, with the exception of an additional denaturation step of $95^{\circ} \mathrm{C}$ for $10 \mathrm{~min}$. 
Five clones from ' $\mathrm{Ca}$. L. solanacearum'-positive and five clones from ' $C a$. L. solanacearum'- negative psyllid colonies were sequenced. Sequences obtained were searched against the National Center for Biotechnology Information nucleotide database using Blastn program.

Wolbachia wsp gene phylogenetic analyses. The wsp gene sequences obtained from 'Ca. L. solanacearum'-positive and -negative psyllids as well as partial wsp gene sequences from strains of Wolbachia from Zhou et al. (33) were aligned using Clustal X version 2.0.12. (10). Neighbor-joining trees were constructed with Kimura's two-parameter distance using the same program (8). Bootstrapping with 1,000 replicates was performed. Trees were visualized using MEGA 4.1 freeware (26). The GenBank accession numbers for the nucleotide sequences of the wsp gene are 'Ca. L. solanacearum'-positive wBac1 (BankIt1461884 wsp_wBac1TX2 JN166719), 'Ca. L. solanacearum'-negative wBac1 (BankIt1461884 wsp_wBac1TX1 JN166718), ' $C a$. L. solanacearum'-positive wBac2 (BankIt1461884 wsp_wBac2TX2 JN166717), and 'Ca. L. solanacearum'-negative wBac2 (BankIt1461884 wsp_wBac2TX1 JN166720).

Statistical analyses. To determine whether time differences existed between biological replicates, all life-history parameters were analyzed using two-way analysis of variance (PROC GLM) with effect of pathogen ('Ca. L. solanacearum') and biological replicate (time) as fixed factors and the interaction effect using Minitab (MINITAB v.14; Minitab, Inc., State College, PA). All life-history traits showed normal distribution, with the exception of incubation time, which was $\log _{10}$-transformed prior to analyses.

\section{RESULTS}

Life-history traits of ' $\mathrm{Ca}$. L. solanacearum'-positive and -negative psyllids. Seven-day fecundity. Seven-day fecundity was defined as the number of offspring (number of eggs and nymphs) obtained on the seventh day of the oviposition period. The ' $\mathrm{Ca}$. L. solanacearum'-positive isofemale lines had significantly lower 7-day fecundity than ' $\mathrm{Ca}$. L. solanacearum'-negative lines (Table 1; Fig. 1A and B). The average 7-day fecundity of ' $\mathrm{Ca}$. L. solanacearum'-positive and ' $\mathrm{Ca}$. L. solanacearum'-negative isofemale lines was $26.3 \pm 3.8$ and $41.9 \pm 5.4$ eggs (mean \pm standard error [SE]), respectively.

Hatching percentage. Hatching percentage was determined as number of nymphs hatched out of the total number of eggs deposited. Although there was a trend for decreased hatching percentage in the ' $\mathrm{Ca}$. L. solanacearum'-positive isofemale lines compared with the ' $C a$. L. solanacearum'-negative isofemale lines, it was not significantly different (Table 1). The average hatching percentage of ' $\mathrm{Ca}$. L. solanacearum'-positive and ' $\mathrm{Ca}$. L. solanacearum'-negative lines was $43.1 \pm 6.8$ and $58.1 \pm 7.3 \%$ (mean $\pm \mathrm{SE}$ ), respectively.

Incubation time. The time period between first oviposition and the appearance of first nymphal instar was considered the incubation time. The average incubation time of ' $C a$. L. solanacearum'-positive lines and ' $\mathrm{Ca}$. L. solanacearum'-negative lines was not significantly different $(6.4 \pm 0.3$ and $6.8 \pm 0.3$ days [mean $\pm \mathrm{SE}$, respectively) (Table 1$)$.

Nymphal survival percentage. Nymphal survival was defined as maximum number of adults that emerged out of the maximum number of nymphs produced. We observed a significant interaction effect of ' $\mathrm{Ca}$. L. solanacearum' infection and biological replicate on nymphal survival; however, only ' $C a$. L. solanacearum' infection had a significant main effect (Table 1). The average nymphal survival of ' $\mathrm{Ca}$. L. solanacearum'-positive lines was significantly lower than ' $\mathrm{Ca}$. L. solanacearum'-negative lines (37.3 \pm 5.1 and $56.3 \pm 7.5 \%$ [mean $\pm \mathrm{SE}$ ], respectively) (Fig. 1C and D). Interestingly, there was a significant positive correlation between 7-day fecundity and nymphal survival $(r=0.57, P=$ 0.01 ) for ' $C a$. L. solanacearum'-positive lines but not for the negative lines $(r=0.32, P=0.19)$ (Fig. 1).

Nymphal development time. The time period between the appearance of first instar and first adult emergence was defined as the nymphal development time. The average nymphal development time of ' $C a$. L. solanacearum'-positive and ' $C a$. L. solanacearum'-negative lines was not significantly different $(15.0 \pm 0.3$ and $14.1 \pm 0.7$ days [mean $\pm \mathrm{SE}$ ], respectively) (Table 1 ).

Total development time. The time period from egg laying to the first adult eclosion was considered the total developmental time. The average total development time of ' $\mathrm{Ca}$. L. solanacearum'positive lines was not significantly different than ' $\mathrm{Ca}$. L. solanacearum'-negative lines $(21.2 \pm 0.4$ and $20.9 \pm 0.7$ days [mean \pm $\mathrm{SE}$, respectively) (Table 1).

Sex ratio. There were no significant difference in the sex ratio (percentage female) between ' $\mathrm{Ca}$. L. solanacearum'-positive ( $n=$ $40)$ and ' $\mathrm{Ca}$. L. solanacearum'-negative lines $(n=62)$ (55 and $54.8 \%$, respectively).

Adult mortality index. The mortality index was calculated by multiplying the number of dead individuals per day and the duration of the life span of those insects (days). The greater the mortality index the longer it took for adults to perish. There was no effect of ' $C a$. L. solanacearum' infection $(F=0.5$, df $=1,89$, $P=0.5)$, biological replicate $(F=0.9, \mathrm{df}=1,89, P=0.3)$, or the interaction term $(F=0.2, \mathrm{df}=1,89, P=0.7)$ on mortality index. The mortality index of ' $\mathrm{Ca}$. L. solanacearum'-positive and -negative psyllids was not significantly different $(60.7 \pm 10.7$ and $56.4 \pm 9.6$, respectively). The mean longevity of adult insects was deduced from the formula for mortality index; longevity of ' $\mathrm{Ca}$. L. solanacearum'-positive and -negative adult insects were 14.2 and 11.9 days, respectively.

Symbiotic bacteria associated with ' $\mathrm{Ca}$. L. solanacearum'positive and -negative psyllids. As expected, the $\mathrm{P}$ symbiont, $C$. ruddii, was present in ' $\mathrm{Ca}$. L. solanacearum'-positive and -negative founders of all isofemale lines. In contrast, we did not detect the $\mathrm{S}$ symbiont in these insects. We found that adult female founders of ' $\mathrm{Ca}$. L. solanacearum'-positive and -negative isofemale lines had a similar Wolbachia infection rate (100\%). Based on the sequence of wsp gene, Wolbachia strains can be differentiated into 12 clades between two main groups, A and B (33). We sequenced five $w s p$ PCR amplicons from the ' $C a$. L. solanacearum'-positive psyllids, of which three sequences belonged to strain $w B a c l$ and two sequences were $w B a c 2$. In the 'Ca. L. solanacearum'-negative psyllids, we sequenced five $w s p$ fragments, of which four sequences belonged to strain $w B a c l$ and one sequence to $w B a c 2$. All adult female founders from both ' $\mathrm{Ca}$. L. solanacearum'-positive and -negative isofemale lines were infected with the same two strains (wBacl and wBac2) of Wolbachia, both belonging to group B (16) (Fig. 2). There was $100 \%$

TABLE 1. Significance of 'Candidatus Liberibacter solanacearum' infection, biological replicate, and the interaction term on potato psyllid life-history traits

\begin{tabular}{|c|c|c|c|}
\hline Life-history trait & 'Ca. L. solanacearum' effect & Biological replicate (time) effect & 'Ca. L. solanacearum' $\times$ time effect \\
\hline Seven-day fecundity & $F=5.12, \mathrm{df}=1,34, P=0.03$ & $F=0.03, \mathrm{df}=2,34, P=0.97$ & $F=2.50, \mathrm{df}=2,34, P=0.10$ \\
\hline Hatching percentage & $F=2.77, \mathrm{df}=1,34, P=0.11$ & $F=1.32, \mathrm{df}=2,34, P=0.28$ & $F=1.80, \mathrm{df}=2,34, P=0.18$ \\
\hline Incubation time & $F=0.35, \mathrm{df}=1,34, P=0.56$ & $F=3.85, \mathrm{df}=2,34, P=0.06$ & $F=1.74, \mathrm{df}=2,34, P=0.20$ \\
\hline Nymphal survival percentage & $F=6.48, \mathrm{df}=1,34, P=0.02$ & $F=0.50, \mathrm{df}=2,34, P=0.58$ & $F=4.73, \mathrm{df}=2,34, P=0.02$ \\
\hline Nymphal development time & $F=1.80, \mathrm{df}=1,34, P=0.19$ & $F=0.73, \mathrm{df}=2,34, P=0.49$ & $F=2.34, \mathrm{df}=2,34, P=0.12$ \\
\hline Total development time & $F=1.86, \mathrm{df}=1,34, P=0.19$ & $F=0.10, \mathrm{df}=2,34, P=0.91$ & $F=3.26, \mathrm{df}=2,34, P=0.06$ \\
\hline
\end{tabular}


' $C a$. L. solanacearum' infection in the ' $\mathrm{Ca}$. L. solanacearum'-positive isofemale mothers (17 of 17 isofemale lines). In contrast, we did not detect ' $C a$. L. solanacearum' in any of the ' $C a$. L. solanacearum'-negative isofemale founders ( 0 of 18 isofemale lines).

\section{DISCUSSION}

Our study conclusively shows, for the first time, that ' $\mathrm{Ca}$. L. solanacearum' infection of its insect vector is not neutral on tomato. ' $C a$. L. solanacearum' is known to be persistently transmitted and largely heritable $(7,20)$; furthermore, all life stages can acquire the pathogen via feeding on infected plants (horizontal transmission) (7). Hence, it is not surprising that the pathogen may affect the biology of the vector. In the current study, the only two life-history parameters that significantly differed between the ' $C a$. L. solanacearum'-positive and negative psyllid lines were 7-day fecundity and nymphal survival percentage on tomato plants. The average 7-day fecundity of the ' $\mathrm{Ca}$. L. solanacearum'-positive lines was 1.6 times less than the ' $\mathrm{Ca}$. L. solanacearum'-negative lines $(26.3 \pm 3.8$ and $41.9 \pm 5.4$ eggs, respectively). The average nymphal survival of ' $\mathrm{Ca}$. L. solanacearum'-positive psyllids was 1.5 times less than the ' $C a$. L. solanacearum'-negative psyllids $(37.3 \pm 5.1$ and $56.3 \pm 7.5 \%$, respectively). Interestingly, we observed that females that had lower 7-day fecundity also had reduced nymphal survival but this was only detected in the ' $\mathrm{Ca}$. L. solanacearum'-positive lines, not in the negative lines. Real-
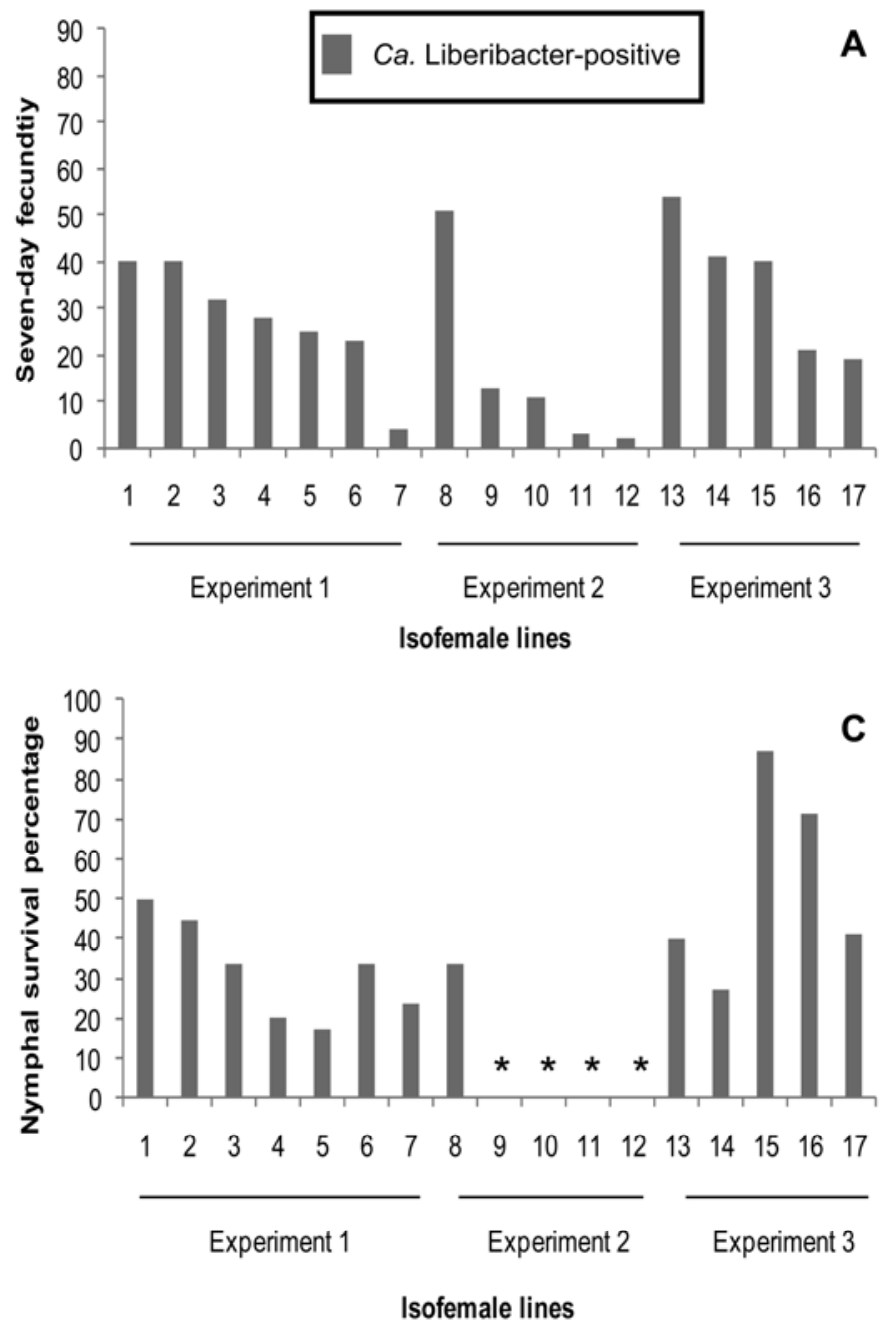

time PCR could be used for measuring abundance of pathogen DNA and determine possible relationships between ' $\mathrm{Ca}$. L. solanacearum' titer and fecundity in potato psyllids. Our results demonstrate that ' $\mathrm{Ca}$. L. solanacearum' negatively affects population growth rate of its vector. No other life-history traits differed between the ' $\mathrm{C} a$. L. solanacearum'-positive and -negative psyllid lines.

The available information in the literature on potato psyllid life history even on the same host plant is inconsistent. For example, Abdullah (2) found that, when males and females were reared together on tomato plants, they lived for the same number of days (41.5 days), regardless of sex; however, when reared separately, females and males lived for 48.7 and 22.0 days, respectively. Other studies have reported potato psyllid longevities of 14.6 to 189 days on potato (9). In the current study, the average longevity of ' $\mathrm{Ca}$. L. solanacearum'-positive insects was not significantly different than ' $\mathrm{Ca}$. L. solanacearum'-negative insects (14.2 and 11.9 days, respectively). There is little published information regarding the effect of environmental factors (temperature, photoperiod, and humidity) on psyllid life cycle; hence, we cannot speculate about the environmental factors contributing to the variation in life-history traits reported in literature. It is also plausible that the observed differences in life-history traits may be due to differences in host plant association, different psyllid biotypes, or effects of Wolbachia spp. or other secondary symbionts that may have a fitness cost on the insect vector. The ' $\mathrm{Ca}$. L. solanacearum'-positive and -negative psyllids were determined to

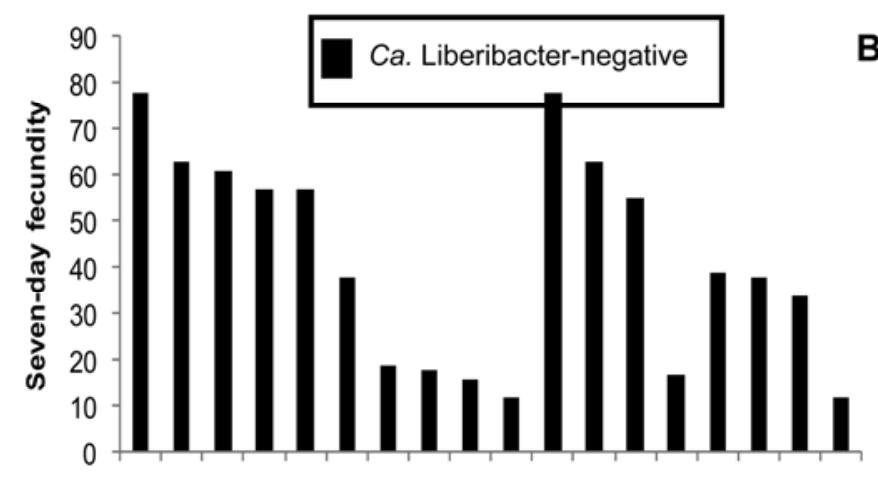

$\begin{array}{llllllllllllllllll}1 & 2 & 3 & 4 & 5 & 6 & 7 & 8 & 9 & 10 & 11 & 12 & 13 & 14 & 15 & 16 & 17 & 18\end{array}$

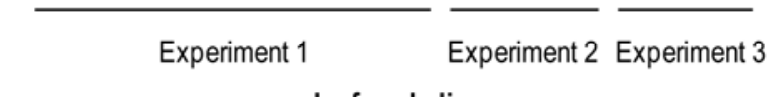

Isofemale lines

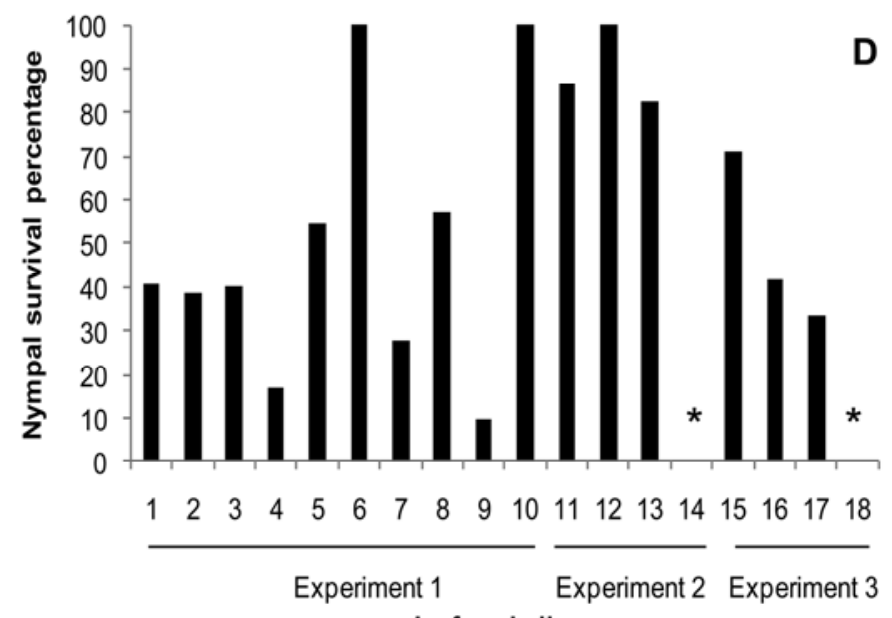

Isofemale lines

Fig. 1. Seven-day fecundity and nymphal survival of isofemale lines. Seven-day fecundity of A, 'Candidatus Liberibacter solanacearum'-positive and B, -negative isofemale lines. Nymphal survival percentage of $\mathbf{C}$, 'Ca. L. solanacearum'-positive and $\mathbf{D}$, -negative isofemale lines. Asterisks indicate $100 \%$ nymphal mortality. 
be of the same biotype using inter-simple-sequence repeat data (Bextine, personal communication).

To rule out the possibility that symbiotic bacteria other than ' $\mathrm{Ca}$. L. solanacearum' may be responsible for the negative fitness of the ' $\mathrm{Ca}$. L. solanacearum'-positive psyllids, we performed PCR analyses using species-specific primers for the $\mathrm{P}$ symbiont, $\mathrm{S}$ symbiont, Wolbachia strains, and ' $\mathrm{Ca}$. L. solanacearum'. The only identified difference between the ' $C a$. L. solanacearum'-positive and -negative psyllid lines was the presence of the bacterium ' $\mathrm{Ca}$. L. solanacearum'. In the absence of the $\mathrm{S}$ symbiont and similar $\mathrm{P}$ symbiont and Wolbachia infection patterns in ' $C a$. L. solanacearum'-positive and -negative isofemale lines, the only bacterial species that appear to differ in the two populations is ' $\mathrm{Ca}$. $\mathrm{L}$. solanacearum'. Further, by using a more sensitive technique, bacterial tag-encoded FLX amplicon pyrosequencing of the $16 \mathrm{~S}$ rDNA genes, we have shown that the symbiotic bacteria in the ' $C a$. L. solanacearum'-positive and -negative psyllids was similar, with the exception of ' $C a$. L. solanacearum' (20).

Current control strategies for potato psyllids only consist of insecticidal sprays. Preventative or alternative management options for ZC disease and potato psyllid must be based on the sound understanding of the ecological basis of vector outbreaks and disease incidence. There has been significant progress in understanding various aspects of the pathogen-vector complex but many important details about the epidemiology and pathogenvector interactions are lacking (5). The information from this study increases our understanding of the epidemiology of ZC disease transmitted by the insect vector, B. cockerelli. The spread of plant pathogens is highly dependent on the biology and ecology of their vector populations. It is also crucial to understand the effects of plant pathogens on vector performance and behavior. Our study indicates that, on tomato, ' $\mathrm{Ca}$. L. solanacearum' has a negative impact on psyllid biology, like many other bacterial and viral plant pathogens. The implications of these findings are that psyllid populations will decline as ' $\mathrm{Ca}$. L. solanacearum' infection rate increases. The observed negative effects of ' $\mathrm{Ca}$. L. solanacearum' on the insect vector need not necessarily occur in all host plant species. For example, positive effects of bacterial infection on host-plant quality may be detectable only on plant species of poor quality or having strong induced defense responses, such as tomato. It is also plausible that ' $\mathrm{Ca}$. L. solanacearum' may confer protection against abiotic stresses or against natural enemies. Future studies may be aimed at elucidating the effect of ' $\mathrm{Ca}$. L. solanacearum' on life-history traits of potato psyllids under varying abiotic and biotic stresses under field conditions.

\section{ACKNOWLEDGMENTS}

This work was supported by Texas Department of Agriculture. A. A. Shapiro was supported by the National Science Foundation-Research Experience for Undergraduates grant awarded to the Department of Entomology, Texas A\&M University. We thank E. Lyuksyutova for helping with PCR analyses, H. Scholthof for psyllid colonies, and two anonymous reviewers for helpful comments.

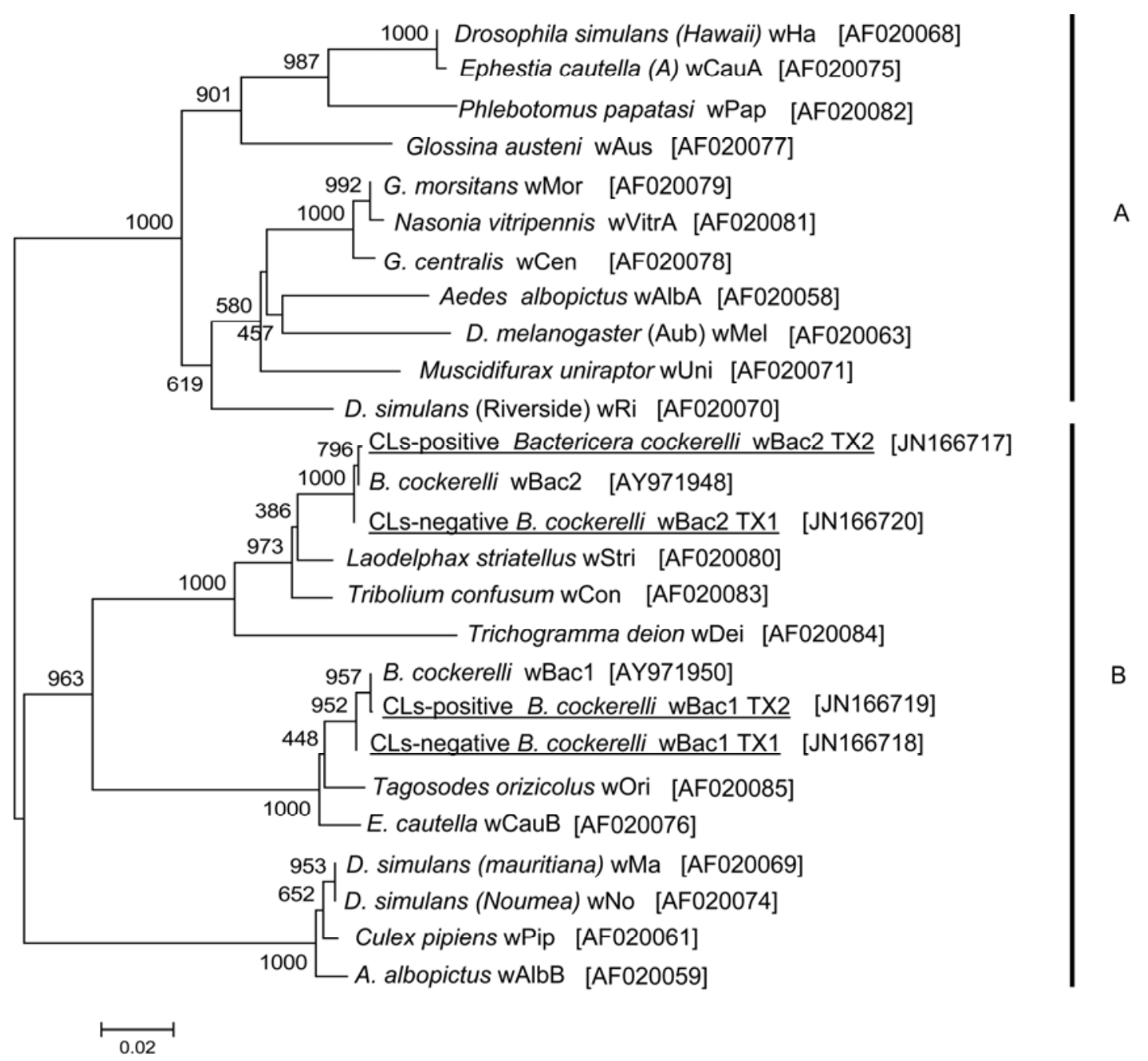

Fig. 2. Phylogenetic tree generated by neighbor-joining analysis based on Wolbachia surface protein (wsp) sequences identified from 'Candidatus Liberibacter solanacearum' (CLs)-positive and CLs-negative psyllids and other known wsp sequences. 


\section{LITERATURE CITED}

1. Abad, J. A., Bandla, M., French-Monar, R. D., Liefting, L. W., and Clover, G. R. G. 2009. First report of the detection of 'Candidatus Liberibacter' species in zebra chip disease-infected potato plants in the United States. Plant Dis. 93:108-108.

2. Abdullah, N. M. M. 2008. Life history of the potato psyllid Bactericera cockerelli (Homoptera: Psyllidae) in controlled environment agriculture in Arizona. Afr. J. Agric. Res. 3:60-67.

3. Baumann, P. 2005. Biology bacteriocyte-associated endosymbionts of plant sap-sucking insects. Annu. Rev. Microbiol. 59:155-189.

4. Crosslin, J. M., and Bester, G. 2009. First Report of 'Candidatus Liberibacter psyllaurous' in zebra chip symptomatic potatoes from California. Plant Dis. 93:551-551.

5. Crosslin, J. M., Munyaneza, J. E., Brown, J. K., and Liefting L. W. 2010. Potato zebra chip disease: a phytopathological tale. Plant Health Progress. Online publication. doi:10.1094/PHP-2010-0317-1001-RV.

6. Hansen, A. K., Jeong, G., Paine, T. D., and Stouthamer, R. 2007. Frequency of secondary symbiont infection in an invasive psyllid relates to parasitism pressure on a geographic scale in California. Appl. Environ. Microbiol. 73:7531-7535.

7. Hansen, A. K., Trumble, J. T., Stouthamer, R., and Paine, T. D. 2008. A new Huanglongbing species, 'Candidatus Liberibacter psyllaurous,' found to infect tomato and potato, is vectored by the psyllid Bactericera cockerelli (Sulc). Appl. Environ. Microbiol. 74:5862-5865.

8. Kimura, M. 1980. A simple method for estimating evolutionary rate of base substitutions through comparative studies of nucleotide sequences. J. Mol. Evol. 16:111-120.

9. Knowlton, G. F., and Janes, M. J. 1931. Studies on the biology of Paratrioza cockerelli (Sulc). Ann. Entomol. Soc. Am. 24:283-291.

10. Larkin, M. A., Blackshields, G., Brown, N. P., Chenna, R., McGettigan, P. A., McWilliam, H., Valentin, F., Wallace, I. M., Wilm, A., Lopez, R., Thompson, J. D., Gibson, T. J., and Higgins, D. G. 2007. Clustal W and Clustal X version 2.0. Bioinformatics 23:2947-2948.

11. Liefting, L. W., Perez-Egusquiza, Z. C., Clover, G. R., and Anderson, J. A. D. 2008. A new 'Candidatus Liberibacter' species in Solanum tuberosum in New Zealand. Plant Dis. 92:1474.

12. Liefting, L. W., Southerland, P. W., Ward, L. I., Paice, K. L., Weir, B. S., and Clover, G. R. G. 2009. A new 'Candidatus Liberibacter' species associated with diseases of solanaceous crops. Plant Dis. 92:208-214.

13. Liefting, L. W., Weir, B. S., Pennycook, S. R., and Clover, G. R. G. 2009. 'Candidatus Liberibacter solanacearum', associated with plants in the family Solanaceae. Int. J. Syst. Evol. Microbiol. 59:2274-2276.

14. Liu, D., and Trumble, J. T. 2004. Tomato psyllid behavioral responses to tomato plant lines and interactions of plant lines with insecticides. J. Econ. Entomol. 97:1078-1085.

15. Liu, D., and Trumble, J. T. 2006. Ovipositional preferences, damage thresholds, and detection of the tomato-potato psyllid Bactericera cockerelli (Homoptera: Psyllidae) on selected tomato accessions. Bull. Entomol. Res. 96:197-204.

16. Liu, D., Trumble, J. T., and Stouthamer, R. 2006. Genetic differentiation between eastern populations and recent introductions of potato psyllid (Bactericera cockerelli) into western North America. Entomol. Exp. Appl. 118:177-183.
17. Moreira, L. A., Iturbe-Ormaetxe, I., Jeffery, J. A., Lu, G., Pyke, A. T., Hedges, L. M., Rocha, B. C., Hall-Mendelin, S., Day, A., Riegler, M., Hugo, L. E., Johnson, K. N., Kay, B. H., McGraw, E. A., van den Hurk, A. F., Ryan, P. A., and O'Neill, S. L. 2009. A Wolbachia symbiont in Aedes aegypti limits infection with dengue, Chikungunya, and Plasmodium. Cell 139:1268-1278.

18. Munyaneza, J. E., Crosslin, J. M., and Upton, J. E. 2007. Association of Bactericera cockerelli (Homoptera: Psyllidae) with "zebra chip", a new potato disease in southwestern United States and Mexico. J. Econ. Entomol. 100:656-663.

19. Munyaneza, J. E., Goolsby, J. A., Crosslin, J. M., and Upton, J. E. 2007. Further evidence that zebra chip potato disease in the lower Rio Grande Valley of Texas is associated with Bactericera cockerelli. Subtrop. Plant Sci. 59:30-39.

20. Nachappa, P., Levy, J., Pierson, E., and Tamborindeguy, C. 2011. Diversity of endosymbionts in the potato psyllid, Bactericera cockerelli (Hemiptera: Triozidae), vector of zebra chip disease of potato. Curr. Microbiol. 62:1510-1520.

21. Oliver, K., Degnan, P. H., Burke, G. R., and Moran, N. A. 2010. Facultative Symbionts in aphids and the horizontal transfer of ecologically important traits. Annu. Rev. Entomol. 55:247-266.

22. Pack, H. J. 1930. Potato psyllid. Utah Agric. Exp. Stn. Bull. 216:21.

23. Pletsch, D. J. 1947. The potato psyllid Paratrioza cockerelli (Sulc), its biology and control. Mont. Agric. Exp. Stn. Bull. 446:95.

24. Secor, G. A., and Rivera-Varas, V. V. 2004. Emerging diseases of cultivated potato and their impact on Latin America. Rev. Latinoam. Papa (Supl.) 1:1-8.

25. Sengoda, G. S., Munyaneza, J. E., Crosslin, J. M., Buchman, J. L., and Pappu, H. R. 2010. Phenotypic and etiological differences between psyllid yellows and zebra chip diseases of potato. Am. J. Pot. Res. 87:4149.

26. Tamura, K. D., J., Nei, M., and Kumar, S. 2007. MEGA4: Molecular Evolutionary Genetics Analysis (MEGA) software version 4.0. Mol. Biol. Evol. 24:1596-1599.

27. Thao, M. L., Clark, M. A., Baumann, L., Brennan, E. B., Moran, N. A., and Baumann, P. 2000. Secondary endosymbionts of psyllids have been acquired multiple times. Curr. Microbiol. 41:300-304.

28. Thao, M. L., Moran, N. A., Abbot, P., Brennan, E. B., Burckhardt, D. H., and Baumann, P. 2000. Cospeciation of psyllids and their primary prokaryotic endosymbionts. Appl. Environ. Microbiol. 66:2898-2905.

29. Wallis, R. L. 1955. Ecological studies on the potato psyllid as a pest of potatoes. Tech. Bull. U. S. Dep. Agric. 1107:1-24.

30. Werren, J. H. 1997. Biology of Wolbachia. Annu. Rev. Entomol. 42:587609.

31. Yang, X., and Liu, T.-X. 2009. Life history and life tables of Bactericera cockerelli (Homoptera: Psyllidae) on eggplant and bell pepper. Environ. Entomol. 38:1661-1667.

32. Yang, X. B., Zhang, Y.-M., Hua, L., and Liu, T.-X. 2010. Life history and life tables of Bactericera cockerelli (Hemiptera: Psyllidae) on potato under laboratory and field conditions in the Lower Rio Grande Valley of Texas. J. Econ. Entomol. 103:1729-1734.

33. Zhou, W., Rousset, F., and O'Neill, S. 1998. Phylogeny and PCR-based classification of Wolbachia strains using wsp gene sequences. Proc. R. Soc. Lond. B. 265:509-515. 